\title{
Nephroprotective and antioxidant effect of aqueous leaf extract of Costus Afer Ker gawl on cyclosporin-a (Csa) induced nephrotoxicity
}

\author{
Anthonet Ndidi Ezejiofor, Nnaemeka Arinze Udowelle and Orish Ebere Orisakwe*
}

\begin{abstract}
Background: Oxidative stress (OS) has been linked to the pathology of a variety of chronic and degenerative diseases. Medicinal plants contain bioactive compounds which are capable of preventing and fighting these diseases. The nephroprotective and antioxidant properties of the aqueous leaf extract of Costus afer (C.afer) against cyclosporine A CSA - induced nephrotoxicity in Wistar albino rats were investigated.

Methods: Six groups of five weight-matched animals each, were used for the study. The first and second groups served as normal and toxic control and were given olive oil and CsA (50 mg/kg b.w.) orally respectively while groups 3, 4, 5 and 6 ingested 375, 750 and $1125 \mathrm{mg} / \mathrm{kg}$ b.w. aqueous leaf extract and $100 \mathrm{mg} / \mathrm{kg}$ b.w. of the Silymarin respectively one hour prior to administration of CsA $50 \mathrm{mg} / \mathrm{kg}$ b.w.

Results: Treatment with C. afer extract at doses of 375, 750 and $1125 \mathrm{mg} / \mathrm{kg}$ prevented the CsA induced nephrotoxicity and oxidative impairments of the kidney, as evidenced by a significantly $(p<0.05)$ reduced plasma creatinine, BUN, $\mathrm{K}^{+}$and renal malondialdehyde (MDA). Furthermore, all the doses were able to induce a significant increment $(P<0.05)$ of renal levels of glutathione $(G S H)$ and plasma superoxide dismutase (SOD) activity, catalase(CAT), glutathione-S-tranferase (GST), serum electrolytes $\left(\mathrm{Na}^{+}\right.$and $\left.\mathrm{HCO}_{3}^{-}\right)$, body and kidney weight. The nephroprotective effects of C.afer extract were confirmed by a reduced severity of renal cellular damage.
\end{abstract}

Conclusion: Aqueous leaf extract of C.afer has a protective role against CSA-induced nephrotoxicity probably mediated through its antioxidant properties.

Keyword: Nephrotoxicity, Costus afer, Antioxidant, Cyclosporine-A, Silymarin

\section{Background}

Indiscrimate use of herbs in treating various diseases has attracted the interest of many researchers in science and medicine to undertake researches that will significantly unfold the medical importance, mechanism of action as well as toxic effect (if any) of these medicinal plants [1]. The organs mostly affected by toxins from medicinal plants include Liver, heart and kidney [2, 3]. Nephrotoxicity is the poisonous effect of some substances including toxic chemicals and medication, on the kidneys characterized by rapid serum creatinine increase and reduction

\footnotetext{
* Correspondence: orishebere@gmail.com

Department of Experimental Pharmacology \& Toxicology, Faculty of Pharmacy University of Port Harcourt, Port Harcourt, Rivers State, Nigeria
}

of glomerular filtration rate (GFR) and may be associated with mild arterial hypertension. Histological changes in renal biopsies reveal tubular, arterial and glomerular changes as well as interstitial fibrosis $[4,5]$. Three clinical syndromes recognized in drug-induced nephropathy include acute renal failure, chronic interstitial nephritis and nephritic syndrome [6, 7]. It can take years for the damage to these organs to be noticeable because there are no symptoms, which is why the kidney disease is often refer to as "silent killer" $[8,9]$.

Cyclosporine A (CsA) is a potent immunosuppressant used for the prevention of organ transplant rejection and in the treatment of autoimmune diseases [10] has been linked with several adverse effects including toxicities 
(nephrotoxicity, hepatoxicity and neurotoxicity), hypertension, dyslipidemia, gingival hyperplasia, hypertrichosis, malignancies and increased risk of cardiovascular events [11], both in transplant and non-transplant settings (autoimmune disorders). Reactive oxygen species (ROS) production and oxidative stress signaling has been implicated in a variety of renal diseases such as IgA nephropathy and chronic kidney disease [10]. Indiscriminate usage of $C$. afer in treatment of diseases in Nigeria and many other countries justify carrying this research and many of its kind. Most medicinal plants used by people are almost always taken in aqueous form either as cold or boiled extract since it has also been reported that the aqueous extract is less toxic than the organic extract [12] These constituents of Costus afer (alkaloids, saponins, flavonoids, tannins and phenols) are potent water soluble antioxidants which prevent oxidizing cell damage $[13,14]$.

Therefore the present study will provide a premise for the discovery of medicines which elicit their medicinal effects through free radical scavenging as this is implicated in a number of degenerative diseases.

\section{Method}

\section{Plant collection}

Costus afer leaves were collected from the Pharmacognosy Garden of the Faculty of Pharmaceutical Sciences, University of Port Harcourt in Ikwerre Local Government Area of Rivers State, Nigeria in January, 2015.

\section{Sample identification}

The plant was taxonomically identified and authenticated by A.O. Ozioko, International Centre for Ethnomedicine and Drug Development (INTERCEDD), University of Nigeria, Nsukka, Enugu State and Professor M.E. Bassey of the Department of Botany, University of Uyo, Akwa Ibom State, Nigeria. The voucher specimen for the same is conserved under the reference number INTERCEDD/034.

\section{Sample processing and extraction}

The leaves was harvested from the stem, washed with clean and shade dried at room temperature for three days. Two hundred and fifty grams of the fresh leaves was weighed chopped into small pieces and ground with a blender. This was macerated in $500 \mathrm{ml}$ of distilled water placed in a stoppered container and allowed to stand for $24 \mathrm{~h}$ with constant agitation. After $24 \mathrm{~h}$, the mixture was strained, the marc was pressed and the liquid was filtered and stored in refrigerator at $4{ }^{\circ} \mathrm{C}$. The solution was discarded every 3 days and the process repeated till the end of the study.

\section{Drugs and chemicals}

Silymarin (Silybon-70), Manufactured by Micro Labs Ltd, Cyclosporine (Sandimmune ${ }^{\circ}$, Neoral ${ }^{\circ}$ ). Silymarin was employed as a standard drug for nephroprotection and antioxidant evaluation. Cyclosporine was used as standard drug to induce nephrotoxicity. Other chemicals and reagents used were of analytical grade.

\section{Experimental animals}

Thirty in-breed male Wistar albino rats $(75.80-162.20 \mathrm{~g})$ acclamitised for two weeks were maintained under controlled conditions of temperature $\left(23 \pm 2{ }^{\circ} \mathrm{C}\right)$ and humidity (50 $\pm 5 \%)$ and a 12-h light-dark cycle, were used for the experiment. The animals were housed in sanitized polypropylene cages containing sterile paddy husk as bedding. The bedding of the cages was changed daily and the cages were cleaned as well. They had free access to standard rat pellet diet and water ad libitum. All the experimental procedures were performed according to the committee for the purpose of control and supervision of experiments on animals, norms and approved by the Institutional Animal Ethical Committee.

\section{Acute toxicity studies}

Rats were kept overnight fasting prior to drug administration. Animals received a single oral dose $(2,000 \mathrm{mg} /$ $\mathrm{kg}$, body weight) of aqueous leaf extract of Costus afer. After the administration of aqueous leaf extract of Costus afer, food was withheld for further 3-4 h. Animals were observed individually at least once during the first $30 \mathrm{~min}$ after dosing, periodically during the first $24 \mathrm{~h}$ (with special attention during the first $4 \mathrm{~h}$ ) and daily thereafter for a period of 14 days. Once daily cage side observations included changes in skin and fur, eyes and mucous membrane (nasal) and also respiratory rate, circulatory (heart rate and blood pressure), autonomic (salivation, lacrimation, perspiration, piloerection, urinary incontinence, and defecation) and central nervous system (ptosis, drowsiness, gait, tremors and convulsion) changes. Mortality, if any, was determined over a period of two weeks [15].

\section{Selection of dose of the extract}

$\mathrm{LD}_{50}$ was done as per OECD guidelines for fixing the dose for biological evaluation. The $\mathrm{LD}_{50}$ of aqueous leaf extract of costus afer leaf extract as per OECD guidelines falls under class four values with no signs of acute toxicity at $2000 \mathrm{mg} / \mathrm{kg}$. The biological evaluation was carried out at three different dose range 375, 750 and $1125 \mathrm{mg} / \mathrm{kg}$ body weight representing $(25,50,75 \%$ of $1500 \mathrm{mg}$ ). All doses were given in the volume ranging between $0.42 \mathrm{ml}$ and $1.20 \mathrm{ml}$ orally.

\section{Cyclosporine-a induced nephrotoxicity in Rat}

Thirty male Wistar albino rats were assigned to six weight matched groups of five rats rats each. The experimental period was 10 days. 
Group I: Animals were administered a single dose of distil water $(1 \mathrm{ml} / \mathrm{kg}$, p.o.) daily for 5 days and received olive oil $(1 \mathrm{ml} / \mathrm{kg}$, p. o.) for another five days.

Group II: Animals were administered distil water

( $1 \mathrm{ml} / \mathrm{kg}$, p.o.) once daily for 5 days and received CsA:olive oil (1:1, $50 \mathrm{mg} / \mathrm{kg}$, p. o.) for five days. Group III: Animals received aqueous extract of Costus afer $(375 \mathrm{mg} / \mathrm{kg}$, p.o.) once daily for 5 days and received same dose of extract one hour prior to $50 \mathrm{mg} /$ $\mathrm{kg}$ CsA:olive oil p. o.) for another five days. Group IV: Animals received aqueous extract of Costus afer $(750 \mathrm{mg} / \mathrm{kg}$, p.o.) once daily for 5 days and received same dose of extract one hour prior to $50 \mathrm{mg} /$ kg CsA:olive oil p. o.) for another five days. Group V: Animals received aqueous extract of Costus afer $(1125 \mathrm{mg} / \mathrm{kg}$, p.o.) once daily for 5 days and received same dose of extract one hour prior to $50 \mathrm{mg} /$ kg CsA:olive oil p. o.) for another five days. Group VI: Animals received silymarin (100 mg/kg, p.o.) once daily for 5 days and received same dose of silymarin one hour prior to $50 \mathrm{mg} / \mathrm{kg}$ CsA:olive oil p.

o.) for another five days.

Animals were sacrificed $24 \mathrm{~h}$ after the last treatment. Blood was collected by retero orbital sinus puncture and serum was separated by centrifugation. Rats were sacrificed under ether anesthesia; kidney were excised, rinsed clean in saline, weighed and preserved in $10 \%$ formalin for antioxidant assay and histopathological study.

\section{Antioxidant assay}

For antioxidant analysis, the kidney was minced into small pieces and homogenzed with ice cold $0.05 \mathrm{M}$ potassium phosphate buffer ( $\mathrm{pH}$ 7.4) to make $10 \%$ homogenates. The homogenates were centrifuged at $6000 \mathrm{rpm}$ for $15 \mathrm{mins}$ at $4{ }^{\circ} \mathrm{C}$. The supernatant was collected for the estimation of catalase (CAT) activity using hydrogen peroxide as substrate according to the method of Clairborne [16]. Superoxide dismutate (SOD) was assayed by the method described by Misra and Fridovich [17]. Glutathione-S-transferase (GST) was assayed by the method of Habig et al. [18]. Reduced glutathione (GSH) was determined at $412 \mathrm{~nm}$ using the method described by Sedlak and Lindsay [19] lipid peroxidation was quantified as malondialdehyde (MDA) according to the method describe by Ohkawa et al. [20] and the MDA level was calculated according to the method of Todorova et al. [21] and expressed as $\mu \mathrm{mol} \mathrm{MDA} / \mathrm{mg}$ protein.

\section{Histopathological studies}

Portion of the kidney from all the experimental groups were fixed in $10 \%$ formaldehyde, dehydrated in graded alcohol, cleared in xylene and then embedded in paraffin.
Microtome sections (5 $\mu \mathrm{m}$ thick) were prepared from each kidney sample and stained with heamtoxylin-eosin (H\&E) dye. The sections were examined for the pathological findings.

\section{Statistical analysis}

The data obtained from the experiment was statistically analyzed and expressed as Mean \pm Standard deviation (SD) using SPSS (Statistical package for social sciences) and one-way analysis of variance (ANOVA) followed by post-hoc Tukey test. Values of " $p<0.05$ were considered statistically significant.

creatinine, $\mathrm{Na}+$ and $\mathrm{HCO}_{3}$ -

\section{Results}

The result of the acute toxicity test carried out using daily cage side observations of the animals, indicates no changes in skin and fur, eyes and mucous membrane (nasal) and also respiratory rate, circulatory (heart rate and blood pressure), autonomic (salivation, lacrimation, perspiration, piloerection, urinary incontinence, and defecation) and central nervous system (ptosis, drowsiness, gait, tremors and convulsion). There was no mortality.

Table 1 shows the effect of $C$. afer on the average body, absolute and relative kidney weight, feed and fluid intake of CsA induced nephrotoxic rat. There was no significant change in average body weight, absolute and relative weight of kidney, feed and fluid intake compared with the normal control in all the groups. There was a marked reduction in body weight gain of the toxic control group compared with other groups.

In CsA induced nephrotoxicity, ingestion of CsA resulted in a significant increase in blood urea nitrogen (BUN), serum creatinine and $\mathrm{K}^{+}$whereas the serum $\mathrm{Na}^{+}$ and $\mathrm{HCO}_{3}^{-}$significantly $(p<0.05)$ decreases compared to normal control group. Administering aqueous leaf extract of C. afer significantlyreduced the level of BUN and serum $\mathrm{K}^{+}$in a dose dependent manner (Table 2).

In CsA induced nephrotoxicity, treatment with CsA causes a significant $(p<0.05)$ increase in MDA while GSH, CAT, GPA, SOD and GST significantly $(p<0.05)$ decreases as compared to normal control group. Administering aqueous leaf extract of C.afer significantly $(p<0.05)$ increase the GSH, CAT, GPA, SOD and GST in CsA treated rats as compared to the toxic control (CsA alone) and the MDA was significantly $(p<0.05)$ decreased (Table 3).

In CsA induce nephrotoxicity model normal control rats (Fig. 1a) showed normal glomerular and tubular histology whereas toxic control (CsA alone) group was found to cause distorted tubular shape, cellular infiltration of the tubules (tubulitis), glomerular and blood vessel congestion, and also result in the presence of inflammatory cells in kidney sections (Fig. 1b). The concurrent treatment 
Table 1 Effect of Costus afer on the average body, absolute and relative kidney weight, feed and fluid intake of CsA induced nephrotoxic rat

\begin{tabular}{|c|c|c|c|c|c|c|}
\hline Treatments & $\begin{array}{l}\text { Body Weight Gain(g) } \\
\text { (initial -final BW) }\end{array}$ & $\begin{array}{l}\text { Body Weight } \\
\text { (BW)(g) }\end{array}$ & $\begin{array}{l}\text { Absolute Kidney Weight } \\
(\mathrm{AKW})(\mathrm{g})\end{array}$ & $\begin{array}{l}\text { Relative Kidney } \\
\text { Weight (\%) }\end{array}$ & $\begin{array}{l}\text { Feed intake } \\
(\mathrm{g} / \mathrm{d})\end{array}$ & $\begin{array}{l}\text { Fluid intake } \\
(\mathrm{ml} / \mathrm{d})\end{array}$ \\
\hline NC (1 ml/kg water) & $22.00(29.02 \%)$ & $97.80 \pm 3.35$ & $0.50 \pm 0.08$ & $0.51 \pm 2.36$ & $71.800 \pm 9.46$ & $182.80 \pm 6.88$ \\
\hline TC (CsA (50 mg/kg) & $1.2(0.9 \%)$ & $134.80 \pm 3.56$ & $0.70 \pm 0.05$ & $0.52 \pm 1.40$ & $64.74 \pm 13.24$ & $152.80 \pm 34.65$ \\
\hline $\begin{array}{l}\text { CsA+375 mg/kg CA } \\
\text { extract }\end{array}$ & 12.00 (10.61%) & $125.00 \pm 6.33$ & $0.70 \pm 0.02$ & $0.56 \pm 0.25$ & $68.00 \pm 9.97$ & $170.00 \pm 9.72$ \\
\hline $\begin{array}{l}\text { CsA +750 mg/kg CA } \\
\text { extract }\end{array}$ & 14 (12.99 \%) & $121.80 \pm 5.81$ & $0.63 \pm 0.02$ & $0.52 \pm 0.38$ & $60.70 \pm 14.18$ & $158.50 \pm 22.736$ \\
\hline $\begin{array}{l}\text { CsA }+1125 \mathrm{mg} / \mathrm{kg} \mathrm{CA} \\
\text { extract }\end{array}$ & 13.00 (13.26 \%) & $111.00 \pm 10.77$ & $0.60 \pm 0.07$ & $0.54 \pm 0.62$ & $68.15 \pm 5.51$ & $178.20 \pm 7.24$ \\
\hline $\begin{array}{l}\text { CsA + } 100 \text { mg/ } \\
\text { kgSilymarin }\end{array}$ & $7.0(4.50 \%)$ & $162.20 \pm 5.07$ & $0.80 \pm 0.03$ & $0.49 \pm 0.611$ & $54.30 \pm 16.13$ & $161.50 \pm 24.95$ \\
\hline
\end{tabular}

All values represent Mean \pm Standard deviation ( $\mathrm{n}=5$ ); RKW $=$ AKW/BW $\times 100(\%),[R K W$ relative kidney weight, $A K W$ absolute kidney weight, $B W$ body weight $]$, Body Weight Gain(g) (initial -final BW), Percent weight gain in parentheses

$C A$ costus afer, CSA cyclosporine-A

with the aqueous leaf extract of C.afer dose dependently reduced such changes in kidney histology (Fig. 1c, d and e).

\section{Discussion}

Nephrotoxicity has been previously documented by a number of studies as the most common and clinically significant as well as the most serious adverse effect of cyclosporine [22, 23]. The exact mechanism of CsAinduced nephrotoxicity remains obscure but several studies suggest that a defect in intracellular calcium handling, magnesium deficiency, oxidative stress, and nitric oxide system are involved [24]. Nephrotoxicity due to chronic cyclosporine-A treatment is widely attributed to the generation of reactive oxygen species [25]. It was demonstrated in this study that the administration of $50 \mathrm{mg} / \mathrm{kg}$ CsA for five consecutive days was able to induce nephrotoxicity in rats. It is known that CsA causes vasoconstriction by its direct action on the arterioles. The vasoconstriction is reported to be due to CsA action in blocking mitochondrial calcium release, inducing increased intracellular calcium which causes vasoconstriction [25]. In the present study, increased production of lipid hydroperoxides and a significant decrease in total antioxidants with CsA confirms the role of oxidative stress in CsA induced organ toxicity. It could also be said that the potential mediators of CsA-induced vasoconstriction involves the renal sympathetic nerves, others factors such as angiotensin II, reduced nitric oxide production and alteration of prostaglandin- thromboxane cascade may also account for the pathogenesis of renal dysfunction [26].

Cyclosporine treatment to the rats toxic control (Cyclosporin-A alone) group resulted in significant increase in renal tissue (L-MDA) levels as compared with the extract treated groups $(p<0.05)$. Similarly Amudha et al. showed significant increase in lipid peroxidation during CsA administration which suggests the involvement of reactive oxygen specie (ROS) in the pathogenesis of renal injury. Elevated levels of MDA in renal tissue have been regarded as an indicator for cellular damage due to excess lipid peroxidation processes that occur during malfunctioning of the antioxidant defence system [27]. In contrast, administration of the aqueous extract of $C$. afer as well as silymarin one hour $(1 \mathrm{~h})$ before CsA administration prevented this elevation dose dependently. The ability of $C$. afer to protect lipid peroxidation is in agreement with Uboh et al. [28], who demonstrated that C. afer leaf's juice possess remarkable lipid peroxidation inhibition and radical scavenging activities.

Administration of cyclosporine to normal rats resulted in a significant decrease in renal tissue antioxidant (GSH, GST and SOD) activities as compared with control

Table 2 Effect of aqueous leaf extract of C. afer on BUN, serum creatinine and electrolyte in experimental groups

\begin{tabular}{llllll}
\hline Treatments & $\mathrm{Na}(\mathrm{nmol} / \mathrm{l})$ & $\mathrm{K}(\mathrm{nmol} / \mathrm{l})$ & $\mathrm{Cr}(\mu \mathrm{mol} / \mathrm{l})$ & $\mathrm{BUN}(\mathrm{mmol} / \mathrm{l})$ & $\mathrm{HCO}(\mathrm{mmo} / \mathrm{l})$ \\
\hline NC & $102.00 \pm 27.62^{\mathrm{bc}}$ & $7.10 \pm 0.10$ & $457.00 \pm 73.19$ & $1.40 \pm .60^{\mathrm{b}}$ & $27.33 \pm 1.16$ \\
TC $(\mathrm{CsA}(50 \mathrm{mg} / \mathrm{kg})$ & $36.00 \pm 4.00^{\mathrm{a}}$ & $9.20 \pm 1.15$ & $481.33 \pm 116.43$ & $4.70 \pm 0.98^{\mathrm{ac}}$ & $24.67 \pm 1.16$ \\
CsA+ $375 \mathrm{mg} / \mathrm{kg}$ extract & $57.00 \pm 7.55^{\mathrm{a}}$ & $6.20 \pm 0.90^{\mathrm{b}}$ & $463.33 \pm 41.79$ & $2.13 \pm 0.12^{\mathrm{b}}$ & $27.33 \pm 1.16$ \\
CsA+ $750 \mathrm{mg} / \mathrm{kg}$ Extract & $57.00 \pm 7.55^{\mathrm{a}}$ & $7.30 \pm 1.25$ & $414.67 \pm 64.39$ & $1.63 \pm 0.55^{\mathrm{b}}$ & $26.00 \pm 2.00$ \\
CsA+ $1125 \mathrm{mg} / \mathrm{kg}$ Extract & $58.00 \pm 15.62^{\mathrm{a}}$ & $5.70 \pm 0.17^{\mathrm{b}}$ & $381.33 \pm 63.50$ & $2.87 \pm 0.70^{\mathrm{b}}$ & $24.67 \pm 1.16$ \\
CsA+ Silymarin (100 mg/kg) & $75.33 \pm 75.33^{\mathrm{b}}$ & $7.47 \pm .25$ & $427.33 \pm 83.36$ & $2.13 \pm 0.70^{\mathrm{b}}$ & $24.00 \pm 2.00$ \\
\hline
\end{tabular}

All values represent Mean \pm SD ( $n=5) ; a=p<0.05$ vs Control; $b=p<0.05$ vs $C s A$ alone; $c=p<0.05$ vs Silymarin. $C r$ (creatinine), Ur(blood urea nitrogen) 
Table 3 Effect of aqueous leaf extract of Costus afer and silymarin on antioxidant parameter

\begin{tabular}{|c|c|c|c|c|c|c|}
\hline Treatments & $\begin{array}{l}\mathrm{GSH}(\mu \mathrm{g} / \mathrm{mg} \\
\text { protein) }\end{array}$ & $\begin{array}{l}\text { MDA ( } \mu \mathrm{mol} / \\
\mathrm{mg})\end{array}$ & $\begin{array}{l}\text { Catalase }(\mu \mathrm{g} / \mathrm{mg} \\
\text { protein) }\end{array}$ & $\begin{array}{l}\mathrm{GPA}((\mu \mathrm{g} / \mathrm{mg} \\
\text { protein)) }\end{array}$ & $\begin{array}{l}\mathrm{SOD}((\mu \mathrm{g} / \mathrm{mg} \\
\text { protein)) }\end{array}$ & $\begin{array}{l}\mathrm{GST}((\mu \mathrm{g} / \mathrm{mg} \\
\text { protein)) }\end{array}$ \\
\hline NC (water) & $0.04 \pm 0.001^{b c}$ & $0.04 \pm 0.002^{c}$ & $0.13 \pm 0.01$ & $0.12 \pm 0.006$ & $0.06 \pm 0.003^{b c}$ & $0.83 \pm 0.006^{\mathrm{ab}}$ \\
\hline TC (CsA (50 mg/kg) & $0.03 \pm 0.001^{\mathrm{ac}}$ & $0.05 \pm 0.004^{c}$ & $0.11 \pm 0.01$ & $0.12 \pm 0.006$ & $0.05 \pm 0.002^{\mathrm{ac}}$ & $0.82 \pm 0.012^{\mathrm{ac}}$ \\
\hline $\begin{array}{l}\text { CsA }+375 \text { mg/kg CA } \\
\text { Extract }\end{array}$ & $0.04 \pm 0.002^{b c}$ & $0.03 \pm .005^{\mathrm{ab}}$ & $0.13 \pm 0.01$ & $0.12 \pm 0 \mathrm{E}-7^{b}$ & $0.05 \pm 0.001^{a}$ & $0.76 \pm 0.006^{\mathrm{abc}}$ \\
\hline $\begin{array}{l}\text { CsA }+750 \mathrm{mg} / \mathrm{kg} \mathrm{CA} \\
\text { Extract }\end{array}$ & $0.034 \pm 0.001^{\mathrm{ac}}$ & $0.03 \pm 0.003^{\mathrm{ab}}$ & $0.13 \pm 0.01$ & $0.13 \pm 0.006^{b}$ & $0.05 \pm 0.001^{\mathrm{a}}$ & $0.80 \pm 0.006^{b c}$ \\
\hline $\begin{array}{l}\text { CsA+ } 1125 \mathrm{mg} / \mathrm{kg} \mathrm{CA} \\
\text { Extract }\end{array}$ & $0.046 \pm 0.002^{b}$ & $0.02 \pm 0.001^{\mathrm{acb}}$ & $0.14 \pm 0.01^{b}$ & $0.13 \pm 0.006$ & $0.05 \pm 0.006^{\mathrm{ab}}$ & $0.82 \pm 0.006^{\mathrm{b}}$ \\
\hline $\begin{array}{l}\text { CsA + Silymarin } \\
(100 \mathrm{mg} / \mathrm{kg})\end{array}$ & $0.047 \pm 0.001^{\mathrm{ab}}$ & $0.03 \pm 0.001^{\mathrm{ab}}$ & $0.13 \pm 0.01$ & $0.11 \pm 0.006$ & $0.05 \pm 0.003^{\mathrm{ab}}$ & $0.82 \pm 0.006^{b}$ \\
\hline
\end{tabular}

All values represent Mean \pm SD $(n=5) ; a=p<0.05$ vs NC; $b=p<0.05$ TC; $c=p<0.05$ vs Silymarin. NC normal control, TC toxic control

group $(p<0.05)$. A decrease in CAT and GPA levels which is not significantly different ( $\mathrm{p}=0.32$ and 0.26 respectively) when compared with the control group was also observed in the CsA group. The effect of the CsA administration on the alteration of the CAT and GPA activity exhibits variability in different studies and is attributed to the difference in dose, time and route of exposure in the experimental design. The observed decrease in the catalase activity in CsA treated rats is due to the decreased availability of NADPH which is required for

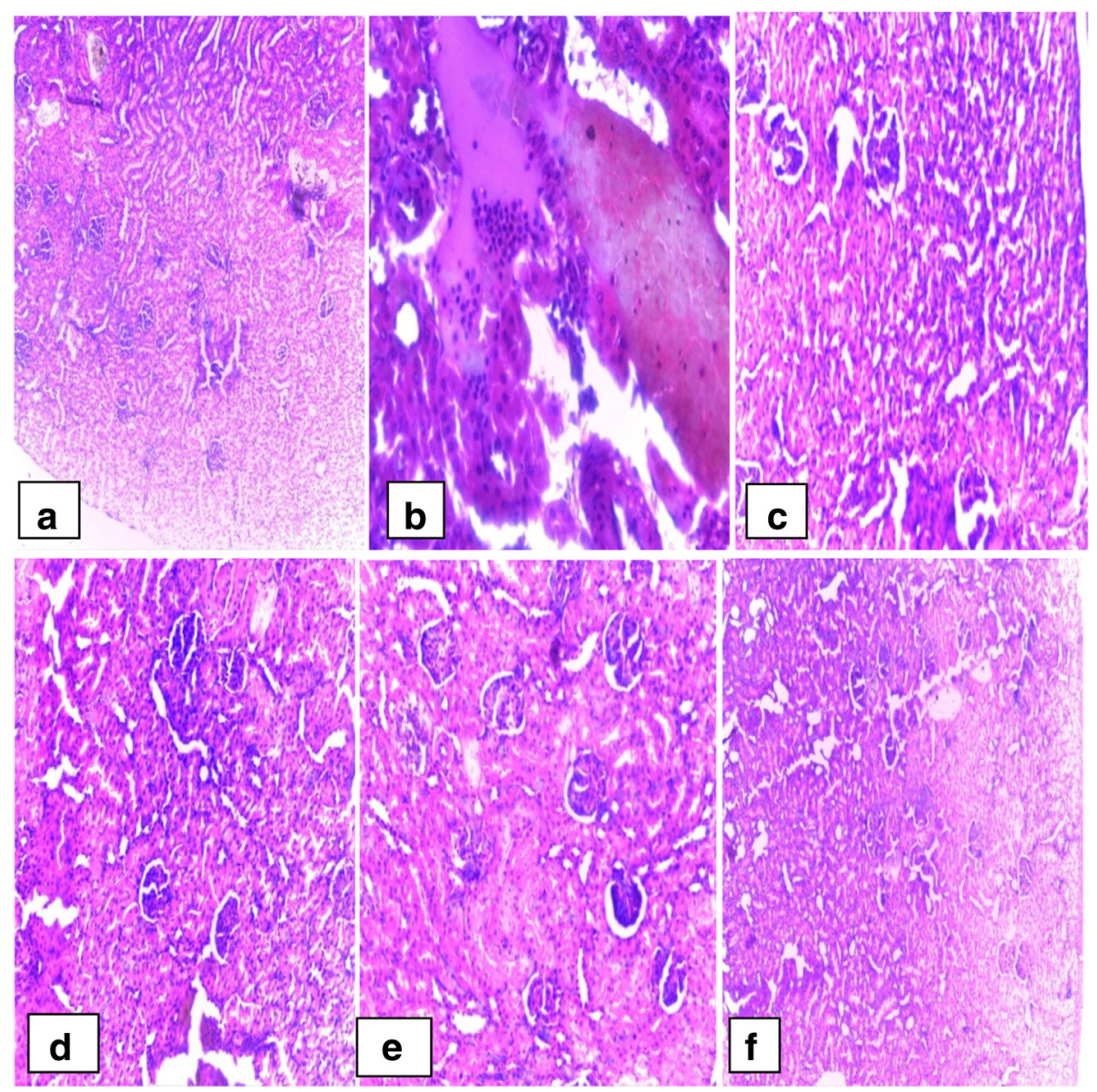

Fig. 1 Effect of aqueous leaf extract of Costus afer on Cyclosporin-A induced nephrotoxicity in rats. a: Normal control; b: Treated cyclosporin (50 mg/kg, p. o.); c: Treated with Costus afer (375 mg/kg); d: Treated with Costus afer (750 mg/kg); e: Treated with Costus afer (1125 mg/kg); f: Treated with silymarin (100 mg/kg). (H \& E X 200) 
catalase activity from its inactive form. Therefore, it is possible that depletion of NADPH production during CsA treatment could decrease the catalase activity. Decrease in the activity of GPA during CsA administration indicates the reduction in the levels of GSH and increase in the levels of peroxides. The depletion of glutathione causes a proportional decrease in hydrogen peroxide detoxification by glutathione peroxidase. The decline in renal antioxidants activity after CsA administration was in agreement with the results reported by Uz et al. [29].

The antioxidants- catalase, SOD, GPA and GSH constitute the major defence against ROS- induced oxidative damage. Superoxide dismutase is considered as the first line of defence against the harmful effects of oxygen radicals in cells, where it scavenges ROS by catalysing the dismutation of superoxide to hydrogen peroxide and oxygen [30]. The administration of C. afer extract concomitantly with cyclosporine resulted in significant increase in renal tissue antioxidant activities as compared with CsA group. These results are in agreement with the study of Anyasor et al. [14] who reported that, the chloroform leaf extract of $C$. afer could serve as a potential source of biopharmaceutical agents with antioxidative property as it was able to restore the antioxidant levels to the control range.

Several important biochemical parameters were also included in this toxicity study. These biological parameters are indicators for organ toxicity. For example, kidney functions were evaluated by means of serum urea, creatinine and electrolyte. Increase of blood creatinine has been shown to be a good indicator of negative impact in kidney functions [31]. An increase in serum renal function tests (urea and creatinine) concentrations were observed in CsA treated rats as compared with control group. The increase in serum urea concentration was significant $(p=0.001)$, while that of creatinine was not significantly different $(p=0.99)$ when compared with the control group. These results are nearly in agreement with the study of Tirkey et al. [24] (2005) who reported that, chronic administration of CsA for 21 days caused a marked impairment of renal function. High levels of plasma urea and creatinine can be used as a rough index of the glomerular filtration rate and indicates several disturbances in kidney. The administration of $C$. afer aqueous extract to cyclosporine treated rats exhibited a decrease in serum renal function (urea and creatinine) levels as compared with CsA group. Similarly, Uboh et al., [28] reported that, administration of $C$. afer extract restored the levels of plasma creatinine and urea to the control range.

Administration of Cyclosporine A rats in toxic control (Cyclosporin-A alone) resulted in a significant decrease in sodium. This result is nearly similar with the study of Chia et al. [26] who found sodium depletion to be associated with CsA treatment. An increase in serum potassium levels was also observed, however, this was not significantly different $(\mathrm{p}=0.06)$ when compared with control group. These results was in agreement with Petrussa et al., who showed that serum potassium level was significantly higher in the CsA group than in the control group and significantly lower in the extract group than in the CsA group. The hyperkalemia seen with calcineurin inhibition is likely multifactorial and relates to inhibitory effects on $\mathrm{Na}$ K-ATPase in collecting ducts and possibly to distal tubular acidosis [32]. Administration of C. afer extract with CsA induced a significant increase in serum sodium levels and a decrease in potassium levels in the CsA + Extract groups. Similarly, Ezejiofor et al. [33] reported that $C$. afer significantly decreased serum sodium, blood urea, and serum creatinine levels in gentamicininduced nephrotoxic rats. There was no significant difference in the serum bicarbonate level of the CsA group when compared with the control group.

Histopathological studies were conducted on vital organ (kidney) of all the rats. According to Wang et al., impaired organs often have abnormal atrophy [34]. The results of this study also showed a marked effect of the CsA administration in terms of the histopathological damages caused on the kidney of the rats in CsA group. The result showed the presence of inflammatory cells in the kidney of the unprotected CsA- induced nephrotoxic rat indicating interstitial inflammation. This is consistent with the reports of Ebru et al. [29] of changes like afferent arteriolopathy, interstitial fibrosis and tubular atrophy. No structural changes were seen in the kidneys of the rats which were given $C$. afer extracts in combination with CsA.

Generally, an increase or decrease in bodyweight of an animal has been used as an indicator of adverse effect of drugs and chemicals [35]. In addition to bodyweight, relative organ weight has also been used as another basic indicator to determine whether the rats have been exposed to harmful agents $[35,36]$. Their organs will tend to swell or damage if they were subjected to toxic substances. This will subsequently alter their organ-to body weight ratios as compared to the respective controls [37]). CsA treatment produced a significant decrease in body weight gain and consequently a decrease in the kidney weight of the CsA group as compared with the control group. This is in agreement with Tariq et al. [38] who reported a decrease in the body weight of the animals in the CsA group. There was an increase in the body weights of the animals in the extract group from day 0 to day 5 as well as day 10 for both control and the CsA + Extract groups. However, the increase in body weight of the animals from day 5 to day10 in the CsA + extract group was not as high as that of the control group. A significant decrease in the food and fluid intake was observed in the CsA group when compared with the control group. These results are in line with the findings of Ezejiofor et al. [33]. 


\section{Conclusion}

Aqueous leaf extract of C.afer has a protective role against CsA-induced nephrotoxicity probably mediated through its antioxidant properties.

\section{Authors' contributions}

ANE: Carried out the bench work and design. NAU: Analysed the data and write up. OEO: Designed the study and write up.

\section{Competing interests}

Anthonet Ndidi Ezejiofor, Nnaemeka Arinze Udowelle and Orish Ebere Orisakwe declare that they have no competing interests.

\section{Source of support}

Nill.

Received: 3 March 2016 Accepted: 18 May 2016

Published online: 30 May 2016

\section{References}

1. Akinsanya A. Rationale of traditional medical therapy. Journal of African Medicinal Plants. 1973;13(3):17-21.

2. Moghaddam AH, Nabavi SM, Nabavi SF, Bigdellou RA, Mohammadzadeh SA Ebrahimzadeh MA. Antioxidant, antihemolytic and nephroprotective activity of aqueous extract of Diospyros lotus seeds. Acta Pol Pharm. 2012;69:687-92.

3. Tanimu, H. and Wudil, A. M. Effect of oral admnistration of aqueous leaves extact of cassia occidentalis on liver and kidney functions in rats. Bayero Journal of Pure and Applied Sciences, 5(2): 31 - 33; 2012 ISSN 2006 - 6996 http://dx.doi.org/10.4314/bajopas.v5i2.5

4. Ryffel B, Mihatsch MJ. Cyclosporine nephrotoxicity. Toxic Patholog. 1986; 14(1):73-82

5. Schrier RW, Wang W, Poole B, Mitra A. Acute renal failure: definitions, diagnosis, pathogenesis and therapy. J of Clin Invest. 2004;114(1):5-14

6. Cockwell P, Stringer S, Marriott J. Acute Kidney Injury. In: R. W, editor. Clinical Pharmacy and Therapeutics. Whittlesea: Churchill Livingstone Elsevier; 2012. p. 255-71.

7. Jaipaul N. Tubulointerstitial Nephritis. The Merck Manual. 2013.

8. Levey AS, Atkins R, Coresh J, Cohen EP, Collins AJ, Eckardt KU, Nahas ME, Jaber BL, Jadoul M, Levin A, Powe N R, Rossert J, Wheeler DC, Lameire N, Eknoyan G. Chronic kidney disease as a global public health problem: approaches and initiatives - a position statement from kidney disease improving global outcomes. Kidney Int. 2007;10:1-5.

9. Bag AK, Mumtaz SF. Hepatoprotective and nephroprotective activity of hydroalcoholic extract of Ipomoea staphylina leaves. Bangladesh Journal of Pharmacology. 2013:8(3):263-8.

10. O'Connell S, Tuite N, Slattery C, Ryan MP, McMorrow T. Cyclosporine a-induced oxidative stress in human renal mesangial cells: a role for ERK 1/2 MAPK signalling. Toxicol Sci. 2011;6:kfr330

11. Olyaei AJ, de Mattos AM, Bennett WM. Immunosuppressant-induced nephropathy: pathophysiology, incidence and management. Drug Saf. 1999; 21(6):471-88.

12. Nwangwu SCO, Josiah SJ, Abubakar TE, Kazeem A, Akinola AA, Osakwe EO. Comparative effect of aqueous and ethanolic extracts of gongronema latifolium on serum, kidney and Liver biomarkers of normal male rats. Asian Journal of Biological Science. 2011;4(7):540-7.

13. Ukpai CF, Agbafor KN, Ndukwu OK, Agwu A, Nwachukwu SN. Phytochemical composition of costus afere extract and its alleviation of carbon tetrachloride -induced hepatic oxidative stress and toxicity. International Journal of Modern Botany. 2012;2(5):120-6.

14. Anyasor GN, Onajobi FD, Osilesi O, Adebawo OO. Proximate composition, mineral content and in vitro antioxidant activity of leaf and stem of Costus afer (Ginger lily). J of Intercultural Ethnopharm. 2014;3(3):128-34

15. OECD. Acute oral toxicity. Acute oral toxic class method guideline 423 adopted 23.03.1996. Eleventh Addendum Bangladesh J Pharmacol. 2013;8: 263-8. 267 to the, OECD, guidelines for the testing of chemicals organization for economics co-operation, development, Paris, June, 2000, p 11.

16. Clairborne A. Catalase activities. Handbook of methods for oxygen radical research. Florida: CRC press; 1995. p. 283-4.
17. Misra HP, Fridovich I. The role of superoxide anion in the autoxidation of epinephrine and a simple assay for superoxide dismutase. J Biol Chem. 1972;25(10):247. 3170-5.

18. Habig WH, Pabst NJ, Jakoby WB. Glutathione -S-transferase. The first enzymatic step in mercapturic acid formation. J Biol Chem. 1974;249(6): 7130-9.

19. Sdelak J, Linday RH. Estimation of total protein, protein bound and non-protein sulfhydryl groups in tissue with ellman's reagent. Anal Biochem. 1996: 25(1):192-205.

20. Ohkawa H, Ohishi N, Yagi K. Assay of lipid peroxidation in animal tissues by thiobarbituric acid reaction. Anal Biochem. 1978:95:351-8.

21. Todorova I, Simeonovo G, Kyuchukova D, Dinev D, And GV. Reference values of oxidative stress parameters ( ${ }^{*} \mathrm{MDA}<\mathrm{SOD}$ and $\left.\mathrm{CAT}\right)$ in dogs abd cats. Comp Clin Pathol. 2005;13:190-4.

22. Burdmann EA, Andoh TF, Yu L, Bennett WM. Cyclosporine nephrotoxicity. Semin Nephrol. 2003;23(5):465-76.

23. Bobadilla NA, Gomba G. New insights into the pathophysiology of cyclosporine nephrotoxicity: a role of aldosterone. Am J of Renal Physio. 2007:293:F2-9.

24. Tirkey N, Kaur G, Vij G, Chopra K. Cucurmin, a diferuloylmethane, attenuates cyclosporine- induced renal dysfunction and oxidative stress in rat kidneys. BMC Pharmacol. 2005:5:15

25. Nagaraja HS, Ravinder RJ, Srikumar C, Thanikachalam P, Nagarajan L, Anupama BK. Apigenin reduces cyclosporine-a induced changes in lipid hydroperoxides and total antioxidants in Sprague Dawley rats. Journal Chinese and Clinical Medicine. 2009:4:26-31.

26. Chia TY, Sattar MA, Abdullah MH, Ahmad FU, Ibraheem ZO, Khoo Joo L, Yen Pei P, Rathore HA, Singh GC, Abdullah NA, John EJ. Cyclosporine a-induced nephrotoxic Sprague-Dawley rats are more susceptible to altered vascular functyion and haemodynamics. International J of Pharm and Pharmaceut Sc. 2012:4(2):1-9.

27. Zariyantey Abdul H, Siti Balkis B, Ng Wen J, Asmah H, Khairana H, Jamaludin M. Nephroprotective effects of Zingiber zerumbet Smith ethyl acetate extract against paracetamol-induced nephrotoxicity and oxidative stress in rats. J Zhejiang Univ-Sci B (Biomed \& Biotechnol). 2012;13(3):176-85.

28. Uboh FE, Saviour U, Eve M, Eyong EU. Effect of costus afer Leaves's juice on nitrocellular thinner induced nephrotoxicity in rats. Res J of Environ Toxicol. 2014;8(1):37-45.

29. Uz E, Uz B, Kaya A, Akdeniz D, Ruzgaresen NB, Uz E, Turgut F, Bayrak R, Akcay A. Protective effect of erdosteine on cyclosporine induced chronic nephrotoxicity in rats. Nephro-Urol Mon. 2012;3(4):280-4.

30. Hussein SA, Ragab OA, El-Eshmawy MA. Protective effect of green Tea extract on cyclosporine a- induced nephrotoxicity in rats. J of Biol Sc. 2014; 14:248-57.

31. Rhiouani H, El-Hilaly J, Israili ZH, Lyoussi B. Acute and sub-chronic toxicity of an aqueous extract of the leaves of Herniaria glabra in rodents. J Ethnopharmacol. 2008;118(3):378-86.

32. Maarten N, Kuypers DRJ, Minnie S. Calcineurin inhibitor nephrotoxicity. Clinical Journal of the Am Soc of Nephrology. 2009:4:481-508.

33. Ezejiofor AN, Orish CN, Orisakwe OE. Effect of aqueous leaves extract of Costus afer Ker Gawl (Zingiberaceae) on the liver and kidney of male albino Wister rat. Anc Sci Life. 2014;33(1):4-9.

34. Wang TC, Su YP, Hsu TY, Yang CC, Lin CC. 28-Day oral toxicity study of the aqueous extract from spider brake (Pteris multifida Poiret) in rats. Food Chem Toxicol. 2007:45(9):1757-63.

35. Teo S, Stirling D, Thomas S, Hoberman A, Kiorpes A, Khetani V. A 90-day oral gavage toxicity study of $\mathrm{d}$-methylphenidate and $\mathrm{d}$, I-methylphenidate in Sprague-Dawley rats. Toxicology. 2002;179(3):183-96.

36. Mohamed EA, Lim CP, Ebrika OS, Asmawi MZ, Sadikun A, Yam MF. Toxicity evaluation of a standardised $50 \%$ ethanol extract of Orthosiphon stamineus. J Ethnopharmacol. 2011;133(2):358-63.

37. Yam MF, Lim CP, Fung Ang L, Por LY, Wong ST, Asmawi MZ, Basir R, Ahmad M. Antioxidant and toxicity studies of $50 \%$ methanolic extract of orthosiphon stamineus benth. BioMed research international. 2013 Dec 30; 2013., Article ID 351602, 10 pages http://dx.doi.org/10.1155/2013/351602.

38. Mohammad T, Christudas M, Samia S, Mohammed Al S, Abdullah Al K. $\mathrm{N}$-acetylcysteine attenuates cyclosporin-induced nephrotoxicity in rats. Nephrol Dial Transplant. 1999;14:923-9. 